\title{
Формирование геологических знаний о Кузнецком угольном бассейне в XVIII - начале XX вв.
}

\section{Кравцова Л.А.}

Институт угля ФИЦ УУХ СО РАН, Кемерово, kravtcovala@yandex.ru

Аннотация. В статье рассматривается процесс формирования геологических знаний о Кузнецком угольном бассейне в период XVIII - первой трети XX вв. Раскрыто значение результатов исследований, направленных на изучение угленосной территории с позиции их осмысления как научной основы для развития угольной промышленности региона. В XVIII в. в связи с экспедициями по изучению Сибири получены начальные сведения о пластах угля. В XIX в. происходило постепенное накопление фрагментарных геологических данных, расширяющих представление о характере угленосных проявлений; были систематизированы и обобщены известные ранее сведения; сформировалось обоснованное предположение о значительности угольных запасов. В начале XX в. геологические исследования, обусловленные коммерческими потребностями регионального уровня и развитием геологии, впервые дают целостное описание геологического строения и угольных ресурсов Кузбасса, наиболее близкое к современному представлению о бассейне и приведшее к заключению о его государственном значении.

Ключевые слова: Кузбасс, Кузнецкий угольный бассейн, изучение Кузбасса, исследователи Кузнецкого бассейна, исследование Кузнецкого угольного бассейна в XVIII - начале XX вв., развитие геологических знаний о Кузбассе.

\section{Formation of geological knowledge about the Kuznetsk coal basin in the XVIII - early XX century}

\section{Kravtsova L.A.}

Coal institute of FRC CCC SBRAS, Kemerovo,kravtcovala@yandex.ru

\begin{abstract}
The article highlights the process of formation of geological knowledge about the Kuznetsk coal basin in the XVIII - early XX century. There are data on the significance of the study results of the coal territory as a scientific base for developing of coal industry in Kuzbass. The initial stage of collecting information about coal seams was in the XVIII century because of plural expeditions for Siberia exploring. The XIX century gave us gradual collecting of different geological data, which expanded our notion about coal; background data were classified. The significance of coal volume was first validated at this period. Geological researches stimulated by regional commercial needs and development of geology, provide the first description of geological structure and coal resources of Kuzbass in the early XX century. This description was the closest to modern knowledge about basin.

Key words: Kuzbass, Kuznetsk coal basin, study of Kuzbass, Kuznetsk basin researchers, Kuznetsk coal basin research in the XVIII - early XX centuries, development of geological knowledge about Kuzbass.
\end{abstract}

В 2021 году Кемеровская область готовится отметить «300-летие образования Кузбасса» (Указ, 2019), в связи с чем рассмотрение процесса формирования научных знаний о бассейне позволит актуализировать вклад геологов не только в развитие науки, но и в историю развития Сибири. Кузнецкий угольный бассейн в настоящее время является крупнейшим углепромышленным регионом России. Научные результаты, полученные исследователями предшествующих поколений и раскрывшие промышленно-экономический потенциал угольных богатств края, способствовали строительству угледобывающих предприятий и развитию инфраструктуры городов, сформировавших современный образ Кемеровской области как шахтерского края. Вместе с тем имена исследователей, внесших вклад в изучение Кузбасса, при рассмотрении истории региона продолжают оставаться малозаметными, что занижает роль геологических изысканий в становлении угольного центра страны.

Согласно периодизации процесса геологического исследования бассейна, разработанной В.И. Яворским, начало его изучения положили исследователь и путешественник Д.Г. Мессершмидт и рудознатец М. Волков, составивший донесение об открытии каменного угля (Яворский, 1962). Факт открытия каменного угля в 1721 г. на территории бассейна имел важное значение, но оставал- 
ся длительное время невостребованным из-за отсутствия экономического запроса, связанного с неосвоенностью Сибири.

Яворский В.И., рассматривая процесс геологического изучения бассейна, отмечает отсутствие должного внимания к углю в начале XVIII в. (Яворский, 1962). Однако, нельзя утверждать, что накопление первоначальных данных о бассейне в этот период отсутствовало. В материалах экспедиции ученого-натуралиста П.С. Палласа (1768-1774 гг.) академиком И.П. Фальком было отмечено наличие «местами» угольных пластов (Нестеровский, 1915). В сведениях партии Линденталя (1786 г.), занимавшейся поиском поделочных пород и минералов, указан пласт угля мощностью до 16 м в обнажении правого берега р. Мрассу. Каменный уголь, пригодный для кузнечных дел, зафиксировал в 1792 г. обер-бергмейстер И.М. Ренованц, исследовавший рудные месторождения Алтая и Салаира. Записи академика Б.Ф.-И. Германа в конце XVIII в. о пластах угля мощностью от 1.5 м до 3.6 м с описанием пород почвы и кровли также имели интерес (Яворский, 1962; Нестеровский, 1915). Эти исследователи положили начало формированию определенного задела первых официальных сведений о наличии угольных месторождений, но по сути это были еще малозначимые факты геологического характера, отмеченные в отчетах и путевых дневниках, поскольку угольные недра не являлись специальным предметом их изучения (Кравцова, 2018).

Начало XIX в. характеризуется более пристальным интересом к проявлениям угля, встречающимся на территории Кузнецкой котловины, дополняя геологическое знание качественно новыми научным сведениями. Штабс-капитан Гернгросс 2-й (А.Р. Гернгросс) впервые сделал правильные выводы о возрасте угля, отнесенного им к каменноугольному периоду (Гернгросс, 1835). 3начительные результаты представила в 1842 г. публикация Соколовского 2-го (Н.А. Соколовский) в Горном журнале, где был изложен анализ качества каменного угля Афонинского месторождения, приведены систематизированные лабораторные данные о выходе летучих веществ, спекаемости, содержании золы, влаги, выделены «разности угля» (Соколовский, 1842), за которыми впоследствии утвердился термин «литотипы угля». Он учел материалы предшествующих разведочных партий (1825, 1827 гг.)., собрал воедино информацию о наличии значительной каменноугольной формации, имеющей промышленную перспективу: «Принимая в расчет обширность каменноугольной Формации Алтайского округа и мощность угольных пластов, не трудно убедиться, какой обильный запас этого горючего материала сокрыт в недрах этой части Сибири для будущей промышленной ея деятельности. ... Каменноугольная Формация заводского округа представляет площадь, не менее 40 тысяч квадратных верст» (Соколовский 2-й, 1842). По мнению академика В.А. Обручева исследования Соколовского 2-го представляли собой «первое подробное изучение угленосных отложений котловины» (Обручев, 1933).

Первая половина XIX в. была также ознаменована ключевым событием, связанным с экспедицией известного путешественника, географа, геолога П.А. Чихачева в Алтайский горный округ в 1842 г. Полученные сведения и характер угленосной площади были осмыслены исследователем как угольный бассейн, который он оконтурил и впервые присвоил ему название - Кузнецкий бассейн (Pierre de Tchihatcheff, 1845). Им была составлена первая геологическая карта в масштабе 1:1000000 (Фомичев, 1940); даны представления о размерах Кузнецкого бассейна. Введение в геологическое знание середины XIX в. термина «Кузнецкий бассейн» обозначило перспективу углепромышленного развития территории. Итак, происходит накопление важной информации геологического характера, которая формирует интерес промышленников, чиновников и специалистов геологических служб, ориентированный на более детальные изыскания.

Во второй половине XIX в. добавляются новые сведения по южной и юго-западной окраинам Кузбасса, представленные в Отчете Штабс-капитана Корженевского и Объяснительной записке Инженер-подполковника Бояршинова (Исследования, 1858). Ими предпринята попытка параллелизации угольных пластов различных месторождений, а составленную геологическую карту П.И. Бутов и В.И. Яворский впоследствии охарактеризовали «первой и для того времени довольно правильной» (Бутов, Яворский, 1922). 
Интенсификация поисково-геологических работ в конце XIX в. была обусловлена строительством Транссибирской железной дороги, которая пролегая по северной части бассейна, являлась основным потребителем угля. В разведочных работах данного периода участвовали А.Н. Державин, А.М. Зайцев, А.А. Краснопольский, П.К. Яворовский. В результате: был выявлен Судженский угленосный район, где с 1897 г. началась добыча угля для нужд железной дороги; внесены уточнения в контуры угленосной площади, границы бассейна расширяются, включая Судженский район (Очерк, 1913). В распространение знаний о Кузнецком бассейне, по утверждению П.И. Бутова и В.И. Яворского, внесли значительный вклад «Труды геологической части Кабинета Е.И.В.», включавшие в себя «сводку всего известного до того времени фактического и литературного материала по геологии Кузнецкого бассейна» (Бутов, Яворский, 1922). К концу ХІХ в., несмотря на крайне низкую геологическую изученность Кузбасса по сравнению с европейскими бассейнами, происходит накопление данных, которые способствуют развитию территории, недавно считавшейся «дикой неразработанной местностью» (Исследования, 1858). В частности, Н.Я. Нестеровским было составлено подробное описание слагающих угленосные отложения пород; А.Н. Державиным детально изучены «как границы угленосного Кузнецкого бассейна, так и породы, слагающие и подстилающие его» (Нестеровский, 1896, №9); Ф.П. Брусницыным открыты несколько месторождений вблизи деревень Беловой, Коневой, Бабанаковой; Д.П. Богдановым впервые установлена юго-западная граница распространения угленосных отложений по р. Чумыш (Крылов и др., 1983). Освоение территорий вдоль транссибирской железной дороги и закладка угольных шахт на основе результатов исследований геологов в Анжерском районе, на Судженском, Щегловском, Кольчугинском, Прокопьевском месторождениях способствуют экономическому развитию края.

В 1913 г. XII сессия Международного геологического конгресса впервые включила в перечень актуальных мировых проблем подсчет запасов угля на планете. Академик П.И. Степанов подчеркивал значимость этой задачи и для России, поскольку «в России общий подсчет геологических запасов еще никем не был произведен» (Степанов, 1952). Подготовленные отечественными геологами к XII сессии конгресса материалы в полном объеме вошли в изданный в 1913 г. труд «Очерк месторождений ископаемых углей России», где были приведены и известные к тому периоду сведения о Кузнецком бассейне (Очерк, 1913). Изученность Кузбасса, как видно из итогового очерка, можно считать не соответствующей возрастающему запросу экономики страны. Однако уже сформированы научные основания считать, «что количество угля в Кузнецком бассейне громадно и едва ли уступает таковому в Донецком бассейне» (Очерк, 1913). Приведенные данные о запасах еще не дают определенности, рассматриваются как «вероятный»-1.125 млрд. т и «возможный»12.5 млрд. т. (Очерк, 1913). Говоря о качестве угля, «с достаточной уверенностью» предполагалось наличие «коксовых», «кузнечных», «пламенных жирных» и «сухих» углей (Очерк, 1913).

Экономические процессы регионального уровня оказывают влияние на интенсификацию геологических исследований Кузбасса, связанных с организацией в 1912 г. и последующей деятельностью Акционерного общества «Копикуз». Необходимость получения сведений о выходах пластов, геологии их залегания и запасах, свойствах углей была обусловлена коммерческим интересом Акционерного общества. Эти исследования были начаты в 1914 г. группой геологов, организованной Л.И. Лутугиным (Кравцова, 2010). В последующий период в изучение бассейна включаются новые партии геологов. В разное время разведочные коллективы возглавляли П.И. Бутов, А.А. Гапеев, В.М. Козловский, В.С. Панкратов, А.А. Снятков, В.И. Яворский, И.С. Яговкин, с 1923 г. С.В. Кумпан и В.Н. Зверев; участвовали горные инженеры В.М. Бажанов, В.В. Вебер, М.К. Елиашевич, Н.К. Разумовский, А.В. Ласточкин, В.Н. Мальцев, В.А. Орестов, В.Н. Покровский, Б.В. Угилович, П.М. Фейгин, М.А. Ющенко, В.Н. Абрамов, Е.В. Доенин, В.И. Лутугин; с начала 1920-х гг. в качестве консультанта привлекался проф. М.А. Усов (Яворский, Бутов, 1927).

Результаты геологических исследований в виде публикаций П.И. Бутова, В.И. Яворского, М.А. Усова, А.А. Гапеева, М.Д. Залесского, В.Н. Вебера, а также отчеты Геолкома вносят важные коррективы и дополнения в сведения о Кузнецком бассейне, пользуются большим спросом при строительстве шахт, рудников. Итоговым трудом, обобщающим запас геологических знаний 
о бассейне в первой четверти XX в., стали геологическая карта бассейна М 1:500000 (1925 г.) и составленная для нее монографическая сводка «Кузнецкий каменноугольный бассейн» П.И. Бутова и В.И. Яворского (1927 г.) (Кравцова, 2011).

Так, к концу третьего десятилетия впервые геология получила близкие к современным «границы распространения угленосных отложений по всем окраинам бассейна», общая площадь которого составила 26180 км²$^{2}$. Было установлено, что Кузбасс располагает широким разнообразием углей, «начиная с тощих (тип полуантрацитов) и до сухих длиннопламенных включительно» (Яворский, Бутов, 1927). Данные о запасах, подсчитанных до 1500 м, П.И. Бутов и В.И. Яворский определили в 400 млрд. т, это превышало данный показатель в Донбассе практически в 8 раз (Яворский, Бутов, 1927). Углепромышленная перспектива Кузбасса получила научное обоснование геологии. Наличие мощных пластов, их угленосность, качественное разнообразие окончательно раскрыли стратегическую значимость бассейна в его будущем развитии.

Таким образом, открытие угля в 1721 г. и масштабные экспедиции по изучению территории Сибири в XVIII в. способствовали появлению первых сообщений о наличии угольных пластов. В первой половине XIX в. благодаря целенаправленному изучению некоторых месторождений угля формируется важная исходная информация о предположительно значимом количестве и мощности пластов угля, его пригодности к кузнечному делу. Выделение П.А. Чихачевым в 1842 г. Кузнецкого бассейна стало существенным фактором привлечения внимания к дальнейшему изучению угольных недр. Вторая половина XIX в. характеризуется получением новых данных по ряду осваиваемых угленосных районов, что способствовало уточнению границ бассейна и формированию научных оснований о внушительных объемах угольных запасов. В начале $\mathrm{XX}$ в. промышленноэкономические задачи регионального значения, связанные с коммерческими интересами Акционерного общества «Копикуз», стали отправной точкой и фактором обстоятельного исследования Кузбасса в период 1914-1927 гг. Результаты изысканий данного периода окончательно сформировали представление о перспективах крупного углепромышленного развития Кузнецкого бассейна в масштабах государственного значения.

\section{Литература}

1. Бутов П.И., Яворский В.И. Материалы для геологии Кузнецкого каменноугольного бассейна. ЮгоЗападная окраина бассейна. Петроград: Типография имени Ивана Федорова. 1922. 58 c.

2. Гернгросс 2-й. Краткий геогностический обзор верхней поисковой дистанции в Алтайских горах. Горный журнал. Т. 2. Кн. 5. 1835. С. 326-337. URL: http://elib.uraic.ru/handle/123456789/6492.

3. Исследования, произведенные в Кузнецком каменноугольном бассейне // Горный журнал 1858. Ч. І. Раздел II. C. 1-35. URL: http://elib.uraic.ru/handle/123456789/6492.

4. Кравцова Л.А. Из истории научных исследований Кузнецкого каменноугольного бассейна // Музеи Российской академии наук: альманах (отв. ред. А.П. Бужилова, С.М. Демкина). М.: ТАУС. 2010. Вып. 8. С. 83.

5. Кравцова Л.А. Исследования Кузнецкого угольного бассейна в XVIII - первой трети XX вв. в динамике развития геологических знаний // Вестник Кемеровского государственного университета. 2018. № 3 (75). C. $27-35$.

6. Кравцова Л.А. Научный потенциал коллекции Музея угля по истории геологических исследований Кузнецкого бассейна // Музей и наука: к 35-летию музея «Археология, этнография и экология Сибири» Кемеровского государственного университета: материалы Междунар. науч. конф. Кемерово. 2011. С. 54-60.

7. Крылов Г.В., Завалишин В.В., Козакова Н.Ф. Исследователи Кузбасса. Кемерово: Кемеровское книжное изд-во. 1983. С. 57-58.

8. Нестеровский Н.Я. К истории открытия каменного угля в Кузнецком угленосном бассейне Алтайского горного округа // Горный журнал. 1915. № 7-9 (июль-август-сентябрь). Т. III. C. 78-87. URL: http://elib. uraic.ru/handle/123456789/1968.

9. Обручев В.А. История геологического исследования Сибири. Период второй (1801-1850). Л.: Изд-во АН CССР. 1933. С. 94.

10. Очерк месторождений ископаемых углей России. СПб.: Типография М.М. Стасюлевича. 1913. С. III, VII, XI, 430, 431.

11. Соколовский 2-й. О каменном угле, найденном близ деревни Афонино и в некоторых других местах Алтайского округа // Горный журнал. 1842. Кн. 4. С. 27, 42. URL: http://elib.uraic.ru/handle/123456789/6572. 
12. Степанов П.И. Воспоминания геолога // Памяти академика П.И. Степанова / Отв. ред. И.И. Горский. М.: Изд-во АН СССР, 1952. С. 73.

13. Указ Президента Российской Федерации «О праздновании 300-летия образования Кузбасса» 27 августа 2018 г. // Администрация Кемеровской области: сайт. URL: https://ako.ru/news/detail/prezident-vladimirputin-podpisal-ukaz-o-prazdnovanii-300-letiya-obrazovaniya-kuzbassa.

14. Фомичев В.Д. Очерки по геологии Сибири. Кузнецкий каменноугольный бассейн. Вып. 11. М.-Л. Изд-во: АН СССР. 1940. С. 5.

15. Яворский В.И. Очерк по истории геологического исследования Кузнецкого бассейна / под ред. В.В. Мокринского. М.: Государственное науч.-техн. изд-во литературы по геологии и охране недр, 1962. С. 3, 9, $10-12$.

16. Яворский В.И., Бутов П.И. Кузнецкий каменноугольный бассейн. Л.: Издание Геологического Комитета. 1927. С. 3, 190-191.

17. Pierre de Tchihatcheff. Voyage scientifique dans L'altai oriental et les parties adjacentes de la frontiẻre da Chine. Paris, 1845. P. 378. URL: http://reader.digitale-sammlungen.de/de/fs1/object/display/bsb10366764_00001.html. 